\title{
Editorial
}

\section{Peter Day's Exploration of Time and Space}

\author{
Santiago Alvarez
}

Citation: Alvarez, S. Peter Day's Exploration of Time and Space.

Magnetochemistry 2021, 7, 103.

https: / / doi.org/10.3390/

magnetochemistry7070103

Received: 7 July 2021

Accepted: 8 July 2021

Published: 13 July 2021

Publisher's Note: MDPI stays neutral with regard to jurisdictional claims in published maps and institutional affiliations.
Departament de Química Inorgànica i Orgànica-Secció de Química Inorgànica-and Institut de Química Teòrica i Computacional, Universitat de Barcelona, Martí i Franquès 1-11, 08028 Barcelona, Spain; santiago@qi.ub.es

\begin{abstract}
Peter Day was one of the most asiduous participants of the NoSIC (Not Strictly Inorganic Chemistry) meetings, where he showed his interest in, and knowledge of, historical, sociological and other non-scientific aspects of the research activities in the institutions led by him as well as in those he visited worldwide, both as a lecturer and as an active participant. This article tries to stress that side of his personality, reflected also in his three autobiographical books, and in his motto "the past is another country", a quotation from L.P. Hartley.
\end{abstract}

Keywords: scientific tourism; biography; conferences

Time and space are the two main axes of Peter Day's non-research essays and books. On the time axis, we find his interest in the history of chemistry and, in particular, the history of the institutions in which he developed his scientific activity: the Royal Institution in London, the Institute Laue-Langevin in Grenoble, and the coffee rooms. The space axis corresponds to the territories he went across during his scientific journey, the specificities of the human atmosphere in each city and town he visited, the social constructs-both political and academic - that float in their atmospheres, and the history that is required to understand how all these factors converged at the time and place of his visit. This two-fold endeavour permeates the three autobiographic books published by Peter Day [1-3], as well as the lectures and communications he gave from 2008 to 2012 in Prullans (Table 1).

Prullans is a small town of the Catalan Pyrenees overseeing the valley of La Cerdanya with the impressive walls of the Cadí mountain range in the background (Figure 1). There, between 2003 and 2018, took place a series of eight NoSIC meetings. NoSIC is a convenient acronym for an odd title, Not Strictly Inorganic Chemistry. The first call stated that the goal was "to gather in a friendly atmosphere about 50 chemists, with research activities in the area of Inorganic Chemistry, to discuss at the interface between Chemistry and other areas of Culture to enhance the permeability of the Chemistry curricula to our cultural and historical background".

Peter Day first participated in the NoSIC-2 meeting, in 2006, kindly accepting my invitation following a suggestion by Michel Verdaguer. The arrangements were facilitated because he had established a second residence in the small village of Marquixanes, in the French Roussillon, in 1997. Marquixanes is barely $85 \mathrm{~km}$ from Prullans, so he could easily drive through the French-Spanish border to attend the meeting. Let me note in passing that his interest for the historical and geographic context as well as for domestic details and human aspects of his environment is well reflected in the description of his life in Marquixanes that appears in a chapter of his book, "On the Cucumber Tree" [2].

He proposed as his lecture's title "The past is another country. But is it?" (L. P. Hartley). The quotation in the title comes from the novel "The Go-Between" by British writer Leslie Pole Hartley (1895-1972). If we consider the full sentence "The past is another country: they do things differently there", it becomes clear that in his mind culture and social structures differ from past to present as from one space (country) to another, and nicely summarizes the two-dimensional perspective of his scientific and human activity worldwide. 
Table 1. Titles and dates of some books published, and lectures given, at the NoSIC meetings in Prullans, by Peter Day, pointing to chapters of his books related to the contents of the talks.

\begin{tabular}{ccll}
\hline Year & Meeting & Book Published & Lectures and Related Book Chapters \\
\hline 2005 & NoSIC-2 & Nature not Mocked [1]. & $\begin{array}{c}\text { "The past is another country..." (L. P. Hartley) But is it? } \\
\text { On the Cucumber Tree, chapter 8. }\end{array}$ \\
2006 & NoSIC-3 & $\begin{array}{c}\text { Benjamin Thomson, Count Rumford-European Citizen and Cooking Expert } \\
\text { Nature not Mocked, chapter 4. }\end{array}$ \\
2008 & NoSIC-4 & $\begin{array}{c}\text { Davy's Batteries: the World's First Research Grant Proposal. } \\
\text { Nature not Mocked, chapter 6. }\end{array}$ \\
2012 & NoSIC-5 & $\begin{array}{c}\text { Conversation Rooms: Coffee and Chemistry. } \\
\text { Nature not Mocked, chapter 2. }\end{array}$ \\
2018 & NoSIC-8 & On the Cucumber Tree [2]. & $\begin{array}{c}\text { Scientific Tourism: Learning About the World Through Travel. } \\
\text { Scientific Tourism }\end{array}$ \\
\hline
\end{tabular}

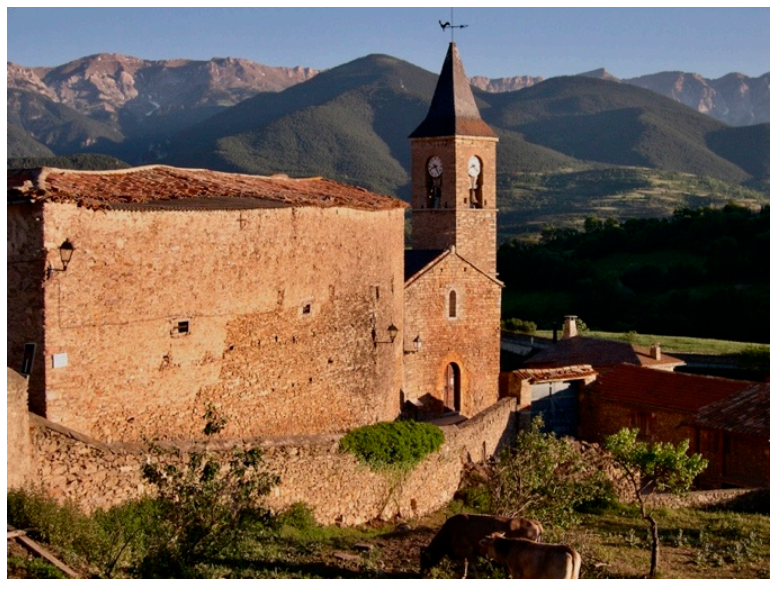

(a)

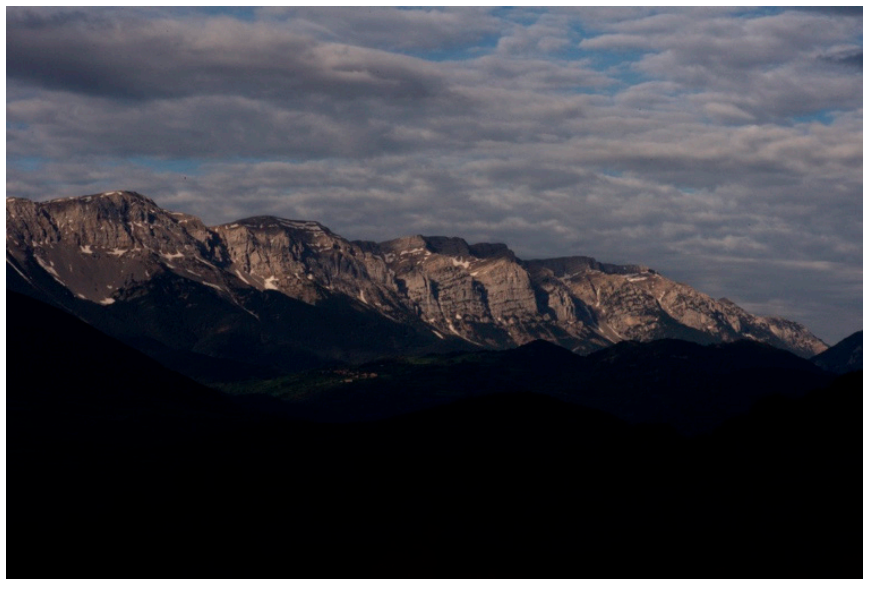

(b)

Figure 1. (a) The Romanesque church of Prullans, 11th-12th century, (b) view of the Cadí mountain range from the NoSIC conference site.

On that occasion, he told a series of interesting stories of the Royal Institution (RI), "the most unusual scientific organisation" of which he had been the director for some years. The three most remarkable leaders of that institution went then on stage: Benjamin Thomson, Humphry Davy and Michael Faraday. He developed further their relevance and less well-known activities in subsequent NoSIC participations (Table 1). First, the physicist Sir Benjamin Thomson, made Count Rumford by the King of Bavaria, whom Day qualified as a "mover and shaker" (one who wants to organise things), and responsible for the establishment of the RI in 1799. He worked on the theory and uses of heat, "heat is nothing but motion", designed lamps and fireplaces, was interested in cooking, and authored a book titled "The Chemistry and Physics of Cooking". Remarks were made also of Davy's famous lectures on laughing gas given in 1810.

Day presented the second director of the RI, Humphry Davy, as the first researcher to write a grant proposal, asking for financial help to make a larger battery for his electrolytic experiments. With that battery, Davy was able to isolate new elements. Quoting Day, "Apart from the Lawrence Berkeley Laboratory under Glenn Seaborg, there can be no other building on the planet that has seen the isolation of so many chemical elements as 21 Albemarle Street under Davy; most of groups 1 and 2 of the periodic table and, at a further remove, chlorine and iodine were identified there". 
He told us about the activity of Michael Faraday, "the young man who left his trade as a bookbinder to come to the RI as Davy's chemical assistant", who started the two famous series of popular lectures, one for adults and one for children in 1826. Less well-known activities of Faraday were also commented upon by Day, such as his contribution to the improvement of steel or the development of optical glass.

By sheer coincidence, two books have become neighbours on the shelves of my domestic library. One, written by Charles Tanford and Jacqueline Reynolds, is "The Scientific Traveler" [4]. Its younger neighbour is Peter Day's Scientific Tourism [3]. In spite of the nearly coincident titles, hardly can two books be more different in their approach to "scientific tourism". Tanford and Reynolds focus on places throughout the world where landmarks in the history of science can be visited, preceded by a general historical and geographical introduction. Peter Day's book, instead, should be considered as a memoir of a scientist on duty, who travels for scientific events and yet observes the natural, urban and human environment.

There are not many coincident geographical spots in the two books, but we can compare, for instance, the sections devoted to Prague. Tanford and Reynolds stress the figures of astronomers Tyco Brahe and Johannes Kepler, who worked under the patronage of King Rudolf II. Their proposed tour for Prague includes a sculpture of both scientists, remains of the palace used by them as residence and observatory, the sepulchre of Brahe in a church, and a plaque that marks the house where Kepler lived. I wish one could find some hints to the activity of famous alchemists contemporary of Brahe and Kepler, with whom they shared the patronage of the King.

In contrast, Peter Day visits Prague in 1969, exactly one year after the Prague Spring during which Czech Prime Minister Alexander Dubcek attempted to promote a "communism with a human face" supported by mass demonstrations of the population that ended with the invasion of the Soviet tanks and the abolition of the political liberalization. He explains several aspects of the conference attended by him within the political context of the moment, without forgetting to mention the theatre where Mozart's opera Don Giovanni was first performed or the simultaneity of the conference organized by the Czechoslovak Academy of Science and the meeting of the Central Committee of the Communist Party that was to decide on the fate of Dubcek. These and other stories were transmitted by Day in Prullans before they got published as a book, with his clear diction, tidy transparencies, and even with his long-fingered hands (Figure 2). To get the flavour of this lecture, the reader is urged to search for Peter Day's quotation of Chaucer's "Canterbury Tales" in his book "Scientific Tourism".

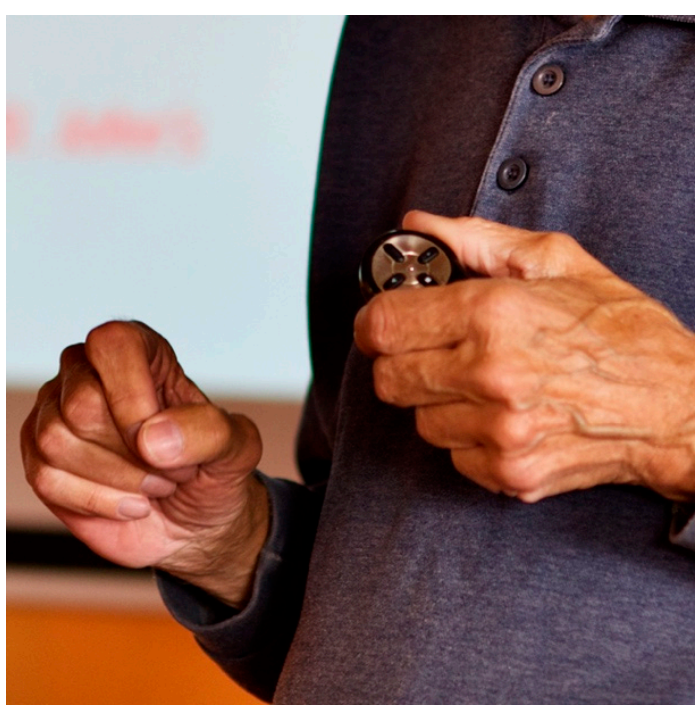

Figure 2. Peter Day's hands during a lecture on Scientific Tourism at NoSiC-8, 8 June 2018. Photo: S. Alvarez. 
The travel chronicles of Peter Day have famous precedents in the history of chemistry. Ludwig Boltzmann, professor of theoretical physics at the University of Vienna, published an account of his travel to California in the summer of 1905 under the title "Reise eines deutschen Professors ins Eldorado", of which two English translations are available [5,6]. The 61-year old scientist travelled by train to Leipzig, continuing to Bremen where he took a steamship to New York. Then, after four days and nights on a railroad, with eventual visits to the smoking car, he made it to San Francisco. While the purpose of the travel was to give a summer course at Berkeley, Boltzmann seems more interested in keeping a record of the social events, meals and drinks than in the scientific aspects of his tour. Two quotations show his gastronomic interest the word "stomach" appears 11 times in the 25 pages of the article:

«Journey to California is champagne, Veuve Clicquot, and oysters. Nobody with any experience in traveling will be surprised when I talk about eating and drinking. It is not only an important factor, it is the central point. It is most important during travel to keep the body healthy in face of the large variety of unaccustomed influences, most of all the stomach, and in particular the pampered stomach of a Viennese [6].»

Even when he comments on the rights of women at the university, his epicureanism emerges:

«It goes without saying that male and female students have equal rights at universities such as these. The same is true of the faculty. I just want to present one drastic example of the far-reaching dominance achieved by the female element. One of my faculty colleagues, Miss Lilian Seraphine Hyde, a not unworthy lady whose name I committed to memory, gave a course of lectures on the preparation of salads and desserts. It was announced in the catalogue just like the course I was giving. I have kept that catalogue as evidence [6].»

Scientific tourism is of a totally different style in the pen of Humphry Davy, who published a book titled "Consolation in Travel" [7]. It describes imagined travels to a few archaeological and natural sites, and his interest is more on spiritual, historical, chemical or cultural issues, often unrelated to the touristic site. The book was written after Davy's recovery "from a long and dangerous illness", "under the same unfavourable and painful circumstances, and at a period when the constitution of the author suffered from new attacks." It was finished on 21 February 1829, but Davy passed away three months later, and the book was published posthumously in 1830.

The book presents Davy's six fictitious dialogues with two friends in Rome, Ambrosio and Onuphrio, in which they deal with history, religion and philosophy. After the first dialogue with his friends, inspired by the impressive ruins of the Roman Colosseum, Davy is immersed in deep reflections and has a vision in which a genius guides him through the evolution of the civilisation. He saw, for instance:

«... that in the place of the rolls of papyrus, libraries were now filled with books. "Behold", the Genius said, "the printing press; by the invention of Faust the productions of genius are, as it were, made imperishable, capable of indefinite multiplication, and rendered an unalienable heritage of the human mind.»

He saw also:

«in the laboratories, alchemists searching for a universal medicine, an elixir of life, and for the philosopher's stone, or a method of converting all metals into gold.»

The subsequent dialogues are in a similar spirit, and they take place during visits to the Vesuvius, the temples of Paestum, the Austrian Alps (this time he travels by himself, and the conversation takes place with an unknown, a philosopher, and Eubathes, a travel companion), and Pola in the peninsula of Istria (Croatia).

There were, however, the short travels of Peter Day from Marquixanes to Prullans that have been important to me and left a deep imprint on me and other colleagues. After Day's 
first participation in a NoSIC, he was enthusiastic and highly encouraging about the style and contents of the meeting and participated in all subsequent editions except when health or family problems prevented him to do so. I have memories of him chatting with whoever happened to be next to him at breakfast, lunch or dinner time, and participating in every discussion after a lecture, as we see in Figure 3a, where he debates with inorganic chemist and poet Ângel Terron after his lecture "Science and Poetry: Exploring the Same Abyss". He had active participation also in the hands-on workshop "Chemical Answers to Culinary Challenges", led by Pere Castells, the chemist behind many of the innovations introduced by the world-famous cook Ferran Adrià, as seen in Figure 3b where he prepares pearls of yoghurt through the spherification process. He formed part of the group that visited the cathedral of La Seu d'Urgell, as recorded in a photograph (Figure 4a) in which he appears in conversation with historian of Chemistry Agustí Nieto-Galán in the cloister.

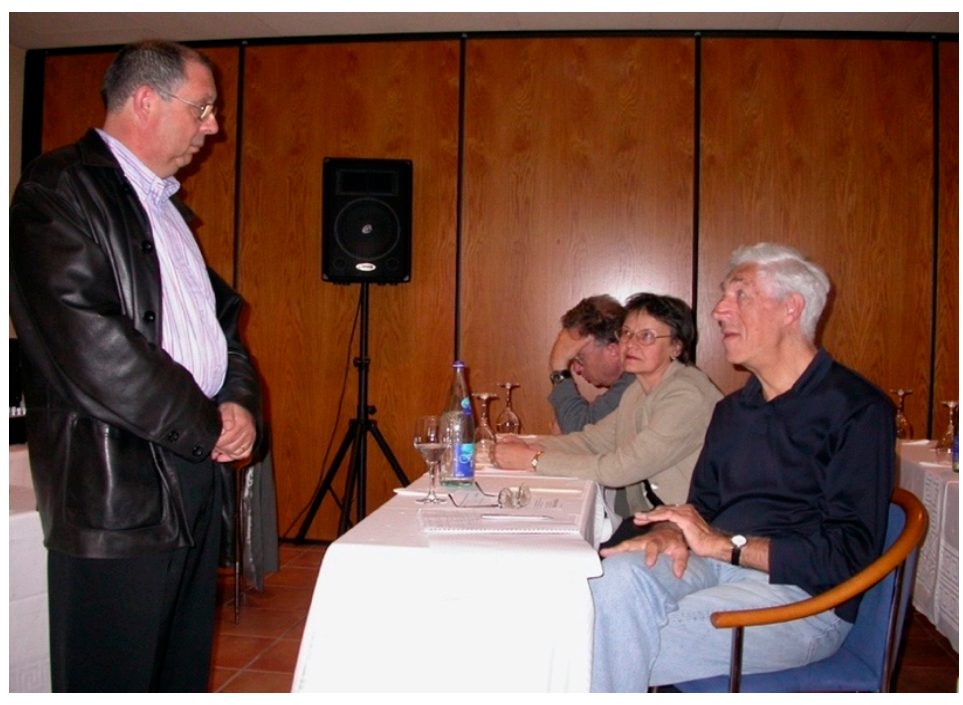

(a)

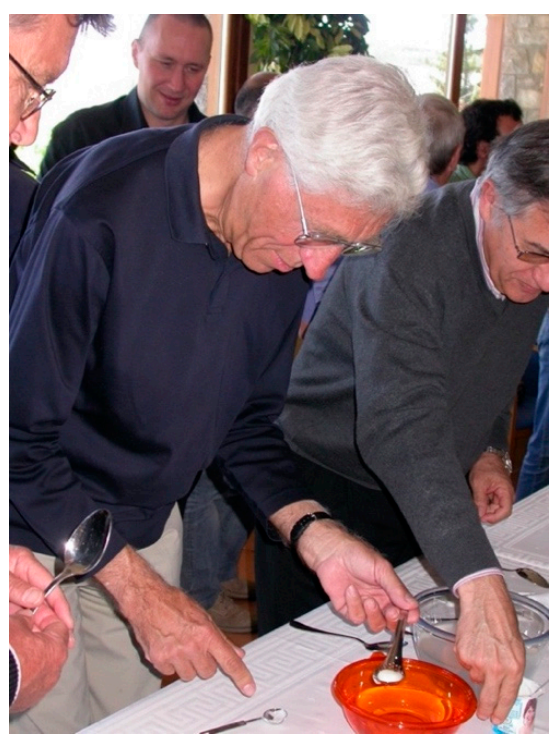

(b)

Figure 3. (a) Àngel Terron debates with Peter Day, with Magdolna and Istvan Hargittai in the background, at NoSIC2, 31 May 2006; (b) Peter Day performs the spherification of a teaspoonful of yoghurt at NoSIC-2, surrounded by Rolf Saalfrank, Mario Ruben and Oriol Rossell. Prullans, 1 June 2006. Photos: S. Alvarez.

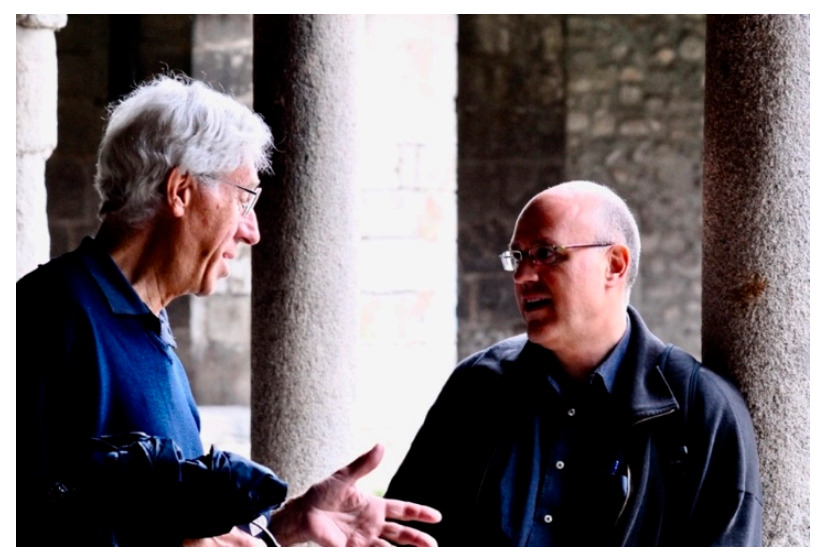

(a)

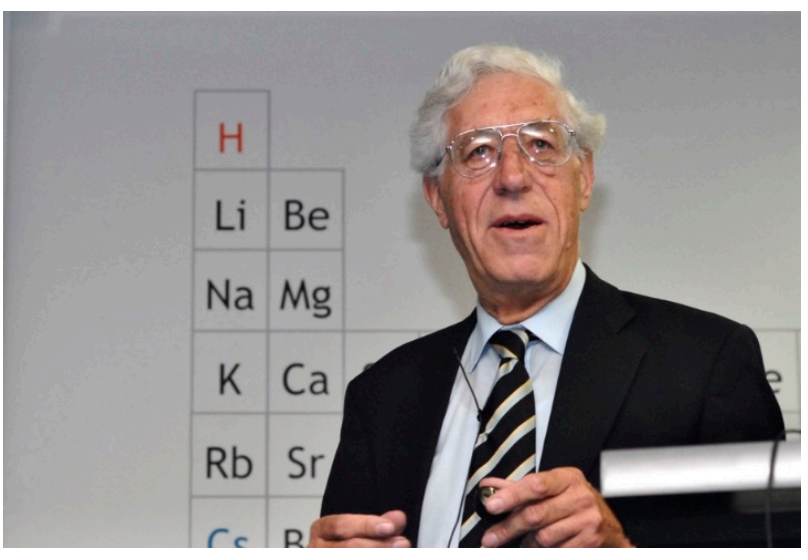

(b)

Figure 4. (a) Peter Day and Agustí Nieto-Galán during a visit to the cathedral of La Seu d'Urgell, 5 June 2008, (b) Day lecturing on the history of magnetism at the University of Barcelona. 8 October 2008. Photos by S. Alvarez.

Remarkably, Peter Day has left us three autobiographical books, yet they are not devoted to his many achievements in science, but rather to explain his perception of the 
many corners of the planet that he travelled to, and of the workings of the academic and scientific institutions that he visited or worked in. One of those books has an apparently odd title, "On the Cucumber Tree" a translation of a Hungarian expression "az uberkafán" that means "on the make" or "on the climb", taken by Day from a novel by English writer William Cooper [8], "nom de plume" of Harry S. Hoff (1910-2002). There are at least four botanical species known as "cucumber tree": Averrhoa bilimbi, Dendrosicyos socotranus, Kigelia africana and Magnolia acuminata. A photograph of the latter illustrates the cover of Day's book. None of them, however, is native to Europe, nor do they produce cucumbers, but fruits of similar shape. It is also interesting to inspect the chronology of his talks at Prullans and the publication of these autobiographical books (Table 1). In some cases, he would lecture about topics already dealt with in one of his books, while on other occasions he would give a talk, equally entertaining and well documented, that would be published later. For him, giving a lecture was something as fluent and natural as talking with a friend at teatime.

Other than the NoSIC meetings, we had a memorable chance to attend a talk delivered by him on the history of magnetism at the University of Barcelona, where he was invited to give the inaugural lecture of the exhibition "Two Millennia of Magnetism" organised by the Rare Books section of the Library of Physics and Chemistry of the University of Barcelona, on 8 October 2008. The lecture "Magnetism-A Mysterious Force of Nature and Some of its Consequences" was praised equally by scientists and non-scientists in the audience. In a picture taken during that event (Figure $4 \mathrm{~b}$ ) he appears to form part of the periodic table of the elements in the front wall of the "Aula Magna Enric Casassas", commonly known as Taula Magna ("taula" is the Catalan for "table").

Before concluding this account, let me quote Peter Day's view on the social role of research institutions and universities, taken from the epilogue of his book "Nature not Mocked":

«The unique positive feature distinguishing the university is the infinite and continuously changing cohort of young people that it brings to the research adventure. It is through fresh approaches that research flourishes most vigorously, and the new generations are its guarantors.»

At the NoSIC meetings, Thursday evening was the time for a special dinner served on long tables. The dates chosen were always at the beginning of June after we finished our teaching duties at the university and before the exams took place. Those were low-season dates for the weekdays at the Hotel Muntanya of Prullans, so we could charge a modest registration fee and be practically the only guests, which facilitated the sense of belonging to a group of friends. In the edition of 2010 during that dinner, a few days before my 60th birthday, I received as a gift a book signed by all the participants. At that point, Peter Day stood up and gave a toast to me with affection and a touch of sarcasm, "Santiago, there is life beyond 60!" he said. I have not forgotten his words, and now am sure that for him there is life beyond life.

Conflicts of Interest: The author declares no conflict of interest.

\section{References}

1. Day, P. Nature Not Mocked: Places, People and Science; Imperial College Press: London, UK, 2005.

2. Day, P. On the Cucumber Tree: Scenes from the Life of an Itinerant Jobbing Scientist, 5th ed.; The Grimsay Press: Glasgow, Scotland, 2012.

3. Day, P. Scientific Tourism: Some Places in the Way; P. Day: London, UK, 2020.

4. Tanford, C.; Reynolds, J. The Scientific Traveler: A Guide to the People, Places \& Institutions of Europe; John Wiley: New York, NY, USA, 1992.

5. Boltzmann, L. Journey of a German Professor to El Dorado. Transp. Theor. Stat. Phys. 1991, 20, 499-523. [CrossRef]

6. Boltzmann, L. A German Professor's Trip to El Dorado. Phys. Today 1992, 45, 44-51. [CrossRef]

7. Davy, H. Consolations in Travel, or the Last Days of a Philosopher; John Murray: London, UK, 1851.

8. Cooper, W. Memoirs of a New Man; Macmillan: London, UK, 1966. 